\title{
EFEKTIVITAS RATIONAL EMOTIVE BEHAVIORAL TRAINING TERHADAP PENURUNAN KECEMASAN MENYUSUN SKRIPSI MAHASISWA
}

\section{THE EFFECTIVENESS OF RATIONAL EMOTIVE BEHAVIORAL TRAINING TO DECREASING ARRANGE MINITHESIS ANXIETY OF COLLEGE STUDENT}

\author{
Kharisma A. Amaliyah \\ Sara Palila \\ Program Studi Psikologi, Fakultas Ilmu Sosial dan Humaniora \\ Universitas Islam Negeri Sunan Kalijaga Yogyakarta \\ Email:kaakeren@yahoo.com
}

\begin{abstract}
This research aims to determine the effectiveness Training of Rational Emotive Behavioral to deriving arrange minithesis anxiety of college student in faculty of sciences and technology $X$ University. The methode of group training REB require to deriving arrange minithesis anxiety. Sample in this research is college student in faculty of science and technology $X$ University that arrange ministhesis. Total of subject in this research is sixteenth college student, that divide into two group 12 subject in control group and 4 subject in experimental group. This research is true experimental and the design used is pretestposttest control group design. The methods of data analysis techniques which used is Mann Whitney $U$ and Wilcoxon. The results of the data analysis between posttest control group and posttest experimental group showed a significance level of $p=0.274$, it means there are not differences of arrange minithesis anxiety between control group and experimental group. The results of differences score pretest and posttest which used Wilcoxon showed a significance level of $p=0.068$. It means there are not differences arrange minithesis anxiety between before and after training. So the conclusion is Training of Rational Emotive Behavioral not effective to deriving arrange minithesis anxiety.
\end{abstract}

Keywords : REBT, arrange minithesis anxiety

\section{INTISARI}

Penelitian ini bertujuan untuk mengetahui pengaruh pelatihan rational emotive behavior. Dengan menggunakan pelatihan rational emotive behavior, individu dapat mengalami penurunan kecemasan menyusun skripsi. Sampel dalam penelitian ini adalah mahasiswa Fakultas Saintek Universitas X di Yogyakarta yang sedang meyusun skripsi. Jumlah subjek dalam penelitian ini adalah 16 mahasiswa, yang dibagi menjadi dua kelompok, 12 orang kelompok kontrol dan 4 orang kelompok eksperimen. Penelitian ini adalah penelitian true eksperimen dengan menggunakan metode pretest-posttest control group design. Teknik analisis data dalam penelitian ini menggunakan Mann Whitney $U$ dan Wilcoxon. Hasil analisis data yang dilakukan antara post-test kelompok kontrol dan kelompok eksperimen menunjukkan taraf signifikan $p=0,274$. Hal ini menunjukkan bahwa tidak terdapat perbedaan kecemasan menyusun skripsi antara kelompok kontrol dan kelompok eksperimen.

Kata Kunci : REBT, Kecemasan Menyusun Skripsi 
Perguruan tinggi adalah suatu penyelenggara pendidikan tinggi yang merupakan kelanjutan dari pendidikan menengah di jalur pendidikan sekolah. Pada prinsipnya perguruan tinggi di Indonesia bertujuan untuk menciptakan manusia-manusia yang berkualitas dan akan menjadi tulang punggung bagi bangsa dan negara. Untuk mencapai tujuan tersebut perguruan tinggi menyelenggarakan kegiatan belajar mengajar, bimbingan, dan latihan (Undang-undang RI nomor 2 tahun 1989 pasal 1). Perguruan tinggi atau universitas dapat menjadi sarana atau tempat bagi individu untuk mengembangkan keilmuan, kepribadian dan melatih kemampuan verbal individu.

Salah satu universitas di Yogyakarta yang menjadi sasaran utama dalam penelitian ini adalah Universitas X. Universitas $\mathrm{X}$ terdiri dari 8 Fakultas, 2 diantaranya Fakultas Umum dan 6 lainnya Fakultas Agama. Fakultas Umum terdiri dari Fakultas Sains dan Teknologi, dan Fakultas Ilmu Sosial dan Humaniora. Fakultas Saintek merupakan salah satu Fakultas yang memiliki jurusan yang terbanyak di Universitas $X$, yaitu 10 jurusan terdiri dari 2 jurusan teknologi (Teknik Informatika, dan Teknik Industri), 4 jurusan pendidikan (Pendidikan Matematika, Pendidikan Kimia, Pendidikan
Fisika, dan Pendidikan Biologi) dan 4 jurusan sains murni (Matematika, Kimia, Fisika dan Biologi). Sedangkan orang yang belajar di perguruan tinggi disebut sebagai mahasiswa (Kamus Besar Bahasa Indonesia, 2002).

Individu yang melakukan kegiatan belajar mengajar di perguruan tinggi adalah mahasiswa. Mahasiswa merupakan peserta didik yang terdaftar dan belajar pada perguruan tinggi atau universitas tertentu. Mahasiswa merupakan sebutan bagi seorang individu yang menjalani pendidikan tinggi di suatu universitas atau perguruan tinggi. Dapat juga dikatakan bahwa mahasiswa termasuk golongan generasi muda yang menuntut ilmu dan merupakan calon intelektual. Mahasiswa dalam tahap perkembangannya digolongkan sebagai remaja akhir dan dewasa awal, yaitu usia 18-21 tahun dan 22-24 tahun (Monk, dkk, 2001). Pada usia tersebut mahasiswa mengalami masa peralihan dari remaja akhir menuju dewasa awal. Menurut Desmita (2009) mahasiswa dalam perkembanganya termasuk dalam kategori dewasa awal yang merupakan masa transisi dari remaja akhir menuju dewasa awal serta pemikiran mahasiswa pada masa tersebut masi sangat labil dan rentang. 
Mahasiswa dapat melakukan kegiatan belajar di dalam kampus maupun diluar kampus. Proses belajar di perguruan tinggi meliputi pertemuan langsung, pertemuan tidak langsung, praktikum, eksperimen dan pemberian tugas akademik lainnya (Hardjana, 1994). Dalam Fakultas Saintek mahasiswa diberikan tugas yang lebih banyak dibandingkan dengan di Fakultas lainnya. Pada setiap pertemuan di kelas tidak jarang Dosen memberikan tugas kepada mahasiswa untuk di kerjakan. Dalam kamus besar berbahasa Indonesia (2002) tugas adalah sesuatu yang wajib dikerjakan dan dilakukan serta menjadi suatu tanggung jawab bagi individu yang mendapatkan tugas tersebut. Tugas akademik biasanya diberikan kepada mahasiswa untuk melatih kemampuan dan daya kritis dalam menanggapi teori, kasus dan realita kehidupan sosial. Tugas merupakan salah satu kewajiban yang di dapat dan diberikan kepada mahasiswa sejak awal semester hingga akhir masa perkuliahan, bahkan tugas menjadi salah satu penentu bagi seorang mahasiswa untuk lulus dalam menjalani perkuliahan. Tugas mahasiswa di perkuliahan beranekaragam, dapat berupa tugas lapangan untuk mengerjakan laporan, dapat juga berupa makalah, dan lain-lain. Khususnya di Fakultas Saintek Universitas X, tidak hanya tugas makalah, tapi ada juga tugas praktikum dan labolatorium yang akan menyita waktu mahasiswa. Di antara kesemua tugas yang diberikan kepada mahasiswa, skripsi merupakan salah satu tugas terpenting dan menjadi penentu akan kelulusan mahasiswa. Tugas akhir atau skripsi adalah karya ilmiah yang diwajibkan sebagai bagian dari persyaratan pendidikan akademis di Perguruan Tinggi (Poerwardarminta, 1983). Penyusunan skripsi yang dibebankan kepada mahasiswa Fakultas Saintek memiliki beban yang lebih dibanding dengan mahasiswa di fakultas lainnya karena diantara kesemuanya penyusunan skripsi harus dibarengi dengan praktikum untuk jurusan murni, pembuatan software bagi jurusan teknologi, dan penelitian terapan untuk jurusan kependidikan sains (Prabawati, 2012).

Tujuan penyusunan skripsi atau tugas akhir adalah untuk menilai kemampuan mahasiswa dalam menyelesaikan masalah, menilai keterampilan dan kemampuan mahasiswa dalam menerapkan metode, dan untuk menilai kemampuan mahasiswa dalam penalaran secara logis (Nindyanti, dkk, 2010). Skripsi adalah karya ilmiah yang diwajibkan sebagai bagian dari persyaratan pendidikan akademis di Perguruan Tinggi (Poerwardarminta, 1983). Semua maha- 
siswa wajib mengambil mata kuliah tersebut, karena skripsi digunakan untuk memperoleh gelar akademisnya sebagai sarjana. Mahasiswa yang menyusun skripsi dituntut menyelesaikan tugas akhirnya dan tidak jarang hal tersebut membuat mahasiswa menjadi cemas karena takut tidak dapat menyelesaikan dengan tepat waktu sesuai target dan mendapat nilai yang tinggi untuk tugas akhirnya. Cemas merupakan faktor emosional yang dapat mempengaruhi diri seseorang dalam bertindak dan berperilaku.

Kecemasan menurut Chaplin (2009) adalah perasaan campur aduk berisikan ketakutan keprihatinan mengenai masamasa mendatang tanpa sebab khusus akan ketakutan tersebut. Kata kecemasan sering kali dianggap sebagai kata yang negatif pada hal kecemasan juga sangat dibutuhkan oleh manusia hanya saja dalam kadar tertentu seperti yang dikemukakan oleh Nevid (2005) bahwa kecemasan bisa bermanfaat bagi kehidupan kita bila kecemasan tersebut dapat mendorong kita untuk melakukan pemeriksaan secara rutin atau memoti-vasi kita untuk belajar lebih kiat lagi sebelum ujian, namun kecemasan bisa menjadi negatif atau abnormal jika proposi dari kecemasan yang dirasakan lebih besar dari pada ancaman yang dihadapi.
Kecemasan adalah suatu keadaan aprehensi atau keadaan kekhawatiran yang dirasakan bahwa akan terjadi sesuatu yang buruk (Nevid, 2005). Deffenbacher (1998) kecemasan adalah rasa takut dan kekhawatiran yang dialami individu mengenai hal yang akan terjadi mendatang dan tidak sesuai dengan harapan yang diinginkan oleh individu, serta dapat menyebabkan individu tersebut mengalami kesulitan konsentrasi, kesulitan dalam mengambil keputusan dan gangguan tidur. Lain halnya dengan kecemasan menurut Yoseph (dalam Sobur, 2003) bahwa kecemasan adalah rasa sudah terkepung, sudah terjepit, dan sudah terperangkap serta berada dalam bahaya. Kecemasan selalu menampakkan diri dalam berbagai bentuk serta intensitas, karena kecemasan merupakan sikap dasar bagi setiap manusia dalam menghadapi setiap bahaya yang mengancam individu. Kecemasan juga didefinisikan sebagai perasaan takut akan suatu tes atau masa depan yang akan terjadi. Menurut Deffenbacher (1985) kecemasan memiliki tiga aspek yaitu kekhawatiran, emosionalitas, serta gangguan dan hambatan dalam mengerjakan tugas.

Mahasiswa sering kali mengalami kecemasan, salah satunya adalah kecemasan menyusun skripsi. Kecemasan menyusun skripsi adalah perasaan tidak 
menyenangkan yang ditandai dengan istilah-istilah kekhawatiran, keprihatinan dan rasa takut yang disebabkan oleh pikiran-pikiran negatif (Linayaningsih, 2007). Kecemasan mengerjakan skripsi juga dialami oleh mahasiswa Program studi Ilmu Keperawatan Fakultas IImu Keperawatan dan Kesehatan Universitas Muhammadiyah Semarang. Berdasarkan penelitan yang oleh Kasmonah kepada 105 mahasiswa Fakultas IImu Keperawatan, terdapat 18,7\% mahasiswa yang mengalami kecemasan mengerjakan skripsi dengan kategori berat, 48,0\% mahasiswa yang mengalami kecemasan mengerjakan skripsi dengan kategori sedang, 24\% mahasiswa yang mengalami kecemasan menyusun skripsi dengan kategori ringan dan 9,3\% mahasiswa yang tidak mengalami kecemasan mengerjakan skripsi.

Dari hasil penelitian yang dilakukan Linayaningsih (2007) pada mahasiswa yang mengerjakan skripsi di Fakultas Psikologi Unika Soegijapranata dapat diketahui bahwa kecemasan mengerjakan skripsi adalah perasaan tidak menentu yang dirasakan oleh individu disebabkan karena keyakinan dan pikiran irasional tentang skripsi. Keyakinan irasional ini dapat berupa individu tidak merasa percaya diri dengan kemampuannya sendiri, takut berhadapan dengan dosen pembimbing, keyakinan bahwa tugasnya akan ditolak dosen pembimbing, dan keyakinan yang salah dari lingkungan yang berupa pernyataan bahwa mengerjakan skripsi itu sulit.

Menurut Ghufron (2012) ada beberapa hal yang dapat menyebabkan kecemasan pada individu, yaitu pengalaman negatif masa lalu dan pikiran yang tidak rasional. Pengalaman negatif masa lalu dapat berupa kegagalan dalam mengerjakan tugas atau penolakan judul yang sering terjadi pada mahasiswa ketika mengajukan judul pada dosen. Sedangkan pikiran yang tidak rasional dapat berupa pikiran takut akan hal yang akan terjadi misalnya takut tidak dapat selesai sesuai target atau takut berhadapan dengan dosen pembimbing karena sudah sering bolak balik untuk melakukan revisi proposal atau skripsi. Hal ini disebabkan oleh kepercayaan dan keyakinan irasional individu akan apa yang akan terjadi pada masa mendatang yang belum tentu menakutkan.

Kecemasan disebabkan oleh pengalaman dahulu yang tidak menyenangkan dan pikiran-pikiran tidak rasional. Namun menurut Iskandar (dalam purnomo, 2009) penyebab utama kecemasan dapat dibagi menjadi dua hal yaitu internal dan eksternal. Penyebab internal dapat berupa kepribadian, 
keinginan dan keyakinan irasional individu. Sedangkan faktor eksternal individu mengalami kecemasan adalah lingkungan sekitar subjek. Dari penjelasan di atas dapat diketahui bahwa kognitif lebih berpengaruh terhadap kecemasan individu, karena hal ini dapat berupa keyakinan dan pikiran-pikiran yang tidak rasional. Wilde (2011) mengungkapkan bahwa salah satu cara untuk mengurangi kecemasan yang dialami oleh individu dapat menggunakan treatment kelompok REBT atau CBT, ia juga mengungkapkan bahwa REBT dapat membantu individu untuk mengontrol kecemasan yang dialaminya yang bersumber dari pikiranpikiran irasional. Pikiran yang irasional dan perasaan ini dapat di modifikasi oleh peneliti dengan menggunakan pelatihan rational emotive behaviour.

Menurut Latipun (2011) REBT memiliki berbagai nama, yaitu Rational therapy, Rasional emotive therapy, Sematic therapy, Cognitive behavior therapy, dan Rational behavior training. REBT dalam teori-teori konseling dikelompokkan sebagai terapi kognitifbehavior. Pencetus dan pelopor REBT adalah Albert Ellis di mana ia memiliki keinginan untuk mengubah perilaku individu yang dilandaskan pada keyakinan irasional dan memengaruhinya agar mau menerima pertimbangan-pertim- bangan yang lebih rasional (Boeree, 2011).

Pada penelitian yang dilakukan oleh Siburian (2010) yang berjudul Pengaruh REBT dalam menurunkan kecemasan akan masa depan pada penyalah guna NAPZA di Panti Rehabilisi menunjukkan bahwa REBT efektif dalam menurunkan kecemasan akan masa depan yang dialami oleh penderita NAPZA. REBT merupakan terapi yang sangat komprehensif, yang menangani masalah-masalah yang berhubungan dengan emosi, kognisi, dan perilaku (Latipun, 2011). Sedangkan menurut Lelono (2011) REBT adalah suatu metode terapi yang menggunakan pendekatan kognitif dan perilaku untuk memahami dan mengatasi masalah emosi dan perilaku negatif yang berasal dari keyakinan-keyakinan yang tidak rasional (irasional). REBT juga berfungsi untuk membongkar pemikiran irasional dari individu. Menurut Ellis (dalam Latipun, 2011) konsep dasar dari REBT ada tiga hal yang terkait dengan perilaku, yaitu antecedent (A), belief (B), dan emotional consequence $(\mathrm{C})$, dan konsep ini dikenal dengan konsep A-B-C.

Konsep A-B-C sangatlah penting bagi teori dan praktek REBT, A adalah keberadaan suatu fakta, suatu peristiwa, tingkah laku atau sikap seseorang. C 
adalah konsekuensi atau reaksi emosional seseorang, yang reaksi ini bisa layak dan tidak layak. Sedangkan B adalah keyakinan individu akan A yang menjadi penyebab C (Corey, 2010). Teori A-B-C merupakan sentral dari teori dan praktek REBT, Ellis (dalam Boeree, 2011) mengemukakan bahwa keyakinan irasional kita dapat memperumit dan memperbesar persoalan yang dihadapi individu. la juga menambahkan $\mathrm{D}$ dan $\mathrm{E}$ untuk rumus A-B-C. D merupakan depute, dimana seorang terapis yang melakukan REBT harus melawan keyakinankeyakinan irasional klien, agar klien dapat menikmati dampak-dampak (effects: E) psikologis positif dari keyakinan rasional.

Dari penelitian yang dilakukan oleh Suhendri, dkk (2012) kepada siswa XI jurusan TKR (teknik kendaraan ringan) SMK Negeri 7 Semarang. Dapat diketahui bahwa pelatihan rational-emotif yang digunakan terbukti dapat mengatasi kecemasan siswa yang akan mengikuti ujian praktek. Hal ini dapat dilihat dari nilai signifikan antara sebelum dan setelah perlakuan sebesar 0.018 $(p<0,05)$, yang membuktikan bahwa ada perbedaan kecemasan yang dialami siswa sebelum dan setelah perlakuan. $\mathrm{Hal}$ ini berarti bahwa pelatihan rationalemotif efektif untuk menurunkan gejala kecemasan yang dialami, berupa takut, cemas, was-was dan ketakutan akan masa depan yang akan dihadapi.

Dari uraian di atas dapat disimpulkan bahwa kecemasan mahasiswa yang sedang menyusun skripsi disebabkan oleh pikiran-pikiran yang tidak rasional akan masa depan yang akan individu jalani, padahal semua itu hanya pikiran irasional dari individu. Pikiran-pikiran inilah yang membuat individu makin cemas ketika menyusun tugas akhir atau skripsi. Oleh karena itu peneliti melakukan penelitian efektivitas pelatihan REB terhadap penurunan kecemasan menyusun skripsi pada mahasiswa Fakultas Saintek Universitas $X$ di Yogyakarta.

\section{METODE PENELITIAN}

\section{Desain Penelitian}

Penelitian ini dilakukan dengan menggunakan metode penelitian eksperimen. Subjek dalam penelitian ditentukan secara random dan dibagi menjadi dua kelompok yaitu kelompok eksperimen dan kelompok kontrol, yang sebelum dilakukan eksperimen terlebih dahulu diberi pre test dan post test diberikan kepada subjek seminggu setelah eksperimen dilakukan. Kelompok eksperimen dalam penelitian ini berjumlah 4 orang 
dan kelompok kontrol dalam penelitian ini berjumlah 12 orang.

\section{Subjek Penelitian}

Adapun kriterian subjek dalam penelitian ini adalah 1) Tercatat sebagai mahasiswa aktif fakultas Saintek Universitas di Yogyakarta, 2) Sedang mengerjakan Skripsi atau tugas akhir, dan 3) Sedang mngalami kecemasan dengan tingkat sedang dan tinggi yang ditentukan dengan skala kecemasan menyusun skripsi.

\section{Metode Pengumpulan Data}

Metode pengumpulan data menggunakan skala kecemasan menyusun skripsi yang disusun sendiri oleh peneliti berdasarkan aspek-aspek kecemasan yaitu kekhawatiran, emosionalitas dan gangguan serta hambatan dalam mengerjakan tugas.

Skala kecemasan menyusun skripsi yang dibuat peneliti menggunakan skala Likert yang berisi pertanyaan-pertanyaan yang bersifat unfavorable dan favorable.
Skala kecemasan menyusun skripsi ini memiliki nilai reliabilitas sebesar 0,941 yang terdiri dari 40 aitem.

\section{Teknik Analisis Data}

Metode analisis data yang digunakan dalam penelitian ini adalah teknik analisis Mann Whitney-U dan Wilcoxon Range Test, dengan menggunakan software Statistical Package Sosial Science (SPSS) versi 17,0 for windows. Tujuan analisis data ini untuk mengetahui perbedaan tingkat kecemasan menyusun skripsi antara kelompok kontrol dan eksperimen serta perbedaan tingkat kecemasan menyusun skripsi pada kelompok eksperimen sebelum dan setelah eksperimen dilakukan

\section{HASIL PENELITIAN}

Berdasarkan hasil analisis data menggunakan uji hipotesis Mann Whitney-U dan Wilcoxon Range Test dapat diketahui nilai signifikan sebagai berikut :

Tabel 1. Hasil Analisis Data

\begin{tabular}{cccc}
\hline & $\mathrm{Z}$ & $\mathrm{p}$ & Keterangan \\
\hline post KK - post KE & -1.093 & 0.274 & Tidak Signifikan \\
\hline pre - post KE & -1.826 & 0.068 & Tidak Signifikan \\
\hline pre -post KK & -1.182 & 0.237 & Tidak signifikan \\
\hline
\end{tabular}


Dari hasil analisis Mann Whitney $\mathrm{U}$ post test kelompok kontrol dan kelompok eksperimen menunjukan bahwa tidak ada perbedaan yang signifikan $(p=0.274)$ antara post test kelompok eksperimen dan kelompok kontrol. Sedangkan hasil analisis Wilcoxon prepost test kelompok eksperimen menunjukkan tidak ada perbedaan yang signifikan $(p=0.068)$ antara sebelum dan setelah perlakuan. Begitu pula pada kelompok kontrol menunjukkan bahwa tidak ada perbedaan yang signifikan $(p=0.237)$.

\section{PEMBAHASAN}

Berdasarkan hasil analisis Mann Whitney $U$ dapat diketahui bahwa skor post-test pada kelompok kontrol dan kelompok eksperimen diperoleh nilai $\mathrm{p}$ $=0.274(p<0.05)$. Hasil ini menunjukkan bahwa tidak ada perbedaan yang signifikan antara post-test kelompok kontrol dan eksperimen atau dengan kata lain tidak ada perbedaan tingkat kecemasan menyusun skripsi antara kelompok yang diberikan pelatihan dan kelompok yang tidak diberikan pelatihan berupa pelatihan REB (rational emotive behavioral). Walaupun jika dilihat dari skor rerata (mean rank) pada kelompok eksperimen sebesar 6.25 sedangkan pada kelompok kontrol sebesar 9.25, yang menunjukkan ada perbedaan mean rank sebesar 3 skor. Hal ini berarti tingkat kecemasan menyusun skripsi peserta kelompok eksperimen lebih rendah dibandingkan dengan tingkat kecemasan menyusun skripsi peserta kelompok kontrol. Walaupun demikian, perbedaan skor ini tidak menunjukkan perbedaan yang signifikan antara kelompok kontrol dan kelompok eksperimen. Tidak adanya perbedaan yang signifikan ini menunjukkan bahwa pelatihan rational emotive behavioral yang diberikan kurang mampu menurunkan tingkat kecemasan menyusun skripsi pada mahasiswa. Hal ini juga berarti bahwa hipotesis kedua penelitian ini ditolak.

Hasil analisis menggunakan Wilcoxon diketahui skor pre-post test pada kelompok eksperimen diperoleh nilai $p=0.068 \quad(p>0.05)$. Hasil ini menunjukkan bahwa tidak ada perbedaan yang signifikan antara sebelum dan setelah terapi. Namun jika dilihat dari mean skor pretest sebesar 81.5 dan mean skor posttest sebesar 58. Dapat dilihat bahwa terjadi penurunan skor setelah kelompok eksperimen diberikan pelatihan rational emotive behavior walaupun tidak cukup signifikan. Dari keempat peserta kelompok eksperimen, terdapat dua peserta eksperimen yang mengalami 
penurunan skor secara drastis, satu peserta mengalami penurunan hingga melompati dua kategorisasi, dan peserta yang selanjutnya turun satu kategorisasi, kedua peserta yang mengalami penurunan skor secara drastis berjenis kelamin perempuan.

Kedua peserta yang lainnya hanya mengalami penurunan skor yang tidak terlalu jauh. Salah satu peserta malah tidak mengalami perpindahan kategorisasi, hal ini dapat disebabkan karena pribadi individu yang mengalami gangguan kepercayaan diri, hal ini terungkap ketika pelatihan sedang berlangsung, subjek mengatakan bahwa ia tidak berani untuk berbicara di depan umun dan tampil di depan umum, hal ini juga terbukti dari sikap pendiam subjek selama pelatihan. Kemudian peserta yang lainnya mengalami penurunan hingga melompati satu kategorisasi. Hal ini juga menunjukkan bahwa hipotesis pertama yang diajukan oleh peneliti ditolak, yang berarti tidak ada perbedaan yang signifikan antara sebelum pelatihan dan setelah pelatihan rational emotive behavioral.

Tidak diterimanya kedua hipotesis dalam penelitian ini disebabkan oleh berbagai hal, yang pertama adalah terjadinya mortality pada saat pelatihan dilaksanakan. Gugurnya peserta pelatihan secara drastis pada saat pelatihan dilaksanakan dapat mempengaruhi nilai variabel perlakuan (Latipun, 2011). Yang kedua adalah jarak antara traetmen hari pertama dan hari kedua yang berjarak kurang lebih seminggu, sehingga peserta tidak menerima materi secara maksimal. Kemudian yang ketiga adalah kurangnya sesi pada pelatihan rational emotive behavioral. Berdasarkan penelitian yang dilakukan oleh Siburian (2010) yang juga melakukan pelatihan REBT pada penderita NAPZA untuk menurunkan kecemasan anak akan masa depan, pelatihan rational emotive behavioral dalam penelitian tersebut dilakukan selama 5 kali pada hari yang berbeda dan diberi jadwal yang ketat. Hal ini menunjukkan bahwa sesi dalam pelatihan rational emotive behavioral yang dilakukan kurang lama sehingga keseluruhan materi tidak dapat tersampaikan secara menyeluruh.

Pelatihan rational emotive behavioral ini disusun berdasarkan tahap-tahap konseling REBT untuk mengurangi kecemasan menyusun skripsi pada mahasiswa, adapun tahap-tahap konseling REBT adalah yang pertama, proses menunjukkan kepada klien bahwa dirinya tidak logis, terapis membantu mereka memahami bagaimana dan mengapa menjadi demikian, dan menunjukkan hubungan antara gangguan 
yang irasional dengan hambaran yang dirasakan. Tahap kedua adalah trainer berusaha membantu klien menyakini bahwa berfikir dapat ditantang dan diubah. Tahap terakhir adalah membantu lebih "mendebatkan" (disputing) gangguan yang tidak tepat atau irasional yang dipertahankan selama ini menuju cara berpikir yang lebih rasional dengan cara reinduktrinasi yang rasional termasuk bersikap secara rasional.

Ditolaknya hipotesis dalam penelitian ini menunjukkan bahwa pelatihan rational emotive behavioral kurang efektif dalam menurunkan kecemasan menyusun skripsi pada mahasiswa yang sedang menyusun skripsi. dapat disimpulkan penyebab ditolaknya hipotesis dalam penelitian ini dikarenakan beberapa keterbatasan. Diantaranya sedikitnya individu yang mau mengikuti pelatihan dikarenakan ketidak sesuaian antara waktu pelaksanaan pelatihan dengan kegiatan individu masing-masing. Kemudian jarak antara pertemuan pertama dan kedua yang terlampau jauh membuat peserta terapi kurang maksimal dalam mengikuti pelatihan Selain itu kelemahan dalam penelitian ini adalah perggantian proses disputing yang hanya dilakukan secara individual dan tidak dilakukan secara kelompok karena keterbatasan peserta pelatihan.
Tidak efektifnya pelatihan rational emotive behavioral disebabkan karena kurangnya interaksi kelompok yang terjadi sehingga tidak terjadi berbagi pengalaman mendalam antar peserta, seperti yang diungkapkan Corey (2010) yang menyatakan bahwa terapi kelompok dapat efektif dilakukan bila interaksi kelompok terjadi secara-terus menerus dan mendalam sehingga mampu memunculkan filsafat-filsafat mendasar yang mampu mengalahkan pikiran irasionalnya, sedangkan dari terapi individu harus dilakukan dalam jangka waktu yang lama dan secara terus menerus, sehingga ada trainer dalam memeriksa memajuan klien secara berkesinambungan dan dapat belajar mengatasi keyakinan-keyakinan irasional sampai ia lebih dari sekedar menghilangkan gejala-gejala, yakni dengan cara belajar hidup lebih toleran dan rasional. Lain halnya yang terjadi saat pelatihan rational emotive behavior, pelatihan hanya berlangsung selama 8 sesi yang masi kurang untuk membantu peserta dalam mengurangi kecemasan menyusun skripsi yang dialaminya.

Pelatihan rational emotive behavioral yang telah dilakukan kurang efektif dalam menurunkan kecemasan menyusun skripsi pada mahasiswa Fakultas Saintek Universitas X di Yogyakarta. Hal ini disebabkan karena pelatihan 
rational emotive behavioral yang telah dilakukan tidak bersifat terapi kelompok, padahal seharusnya dapat berupa terapi kelompok sehingga perlakuan mampu untuk mempengaruhi dan merubah keyakinan-keyakinan irasional peserta pelatihan. Sebagaimana yang di ungkapkan oleh Corey (2010) bahwa terapi dilakukan secara kelompok agar setiap peserta dapat melakukan interaksi dengan peserta yang lain dalam kelompok dan dapat merasakan apa yang dirasakan oleh setiap peserta dalam kelompok. Peserta juga diharapkan agar dapat berbagi pengalaman secara mendalam dan dapat menemukan penyelesaian masalahnya. Terapi kelompok tersebut juga diharapkan dapat merubah keyakinan-keyakinan irasional yang dimiliki oleh peserta dalam terapi kelompok.

Gugurnya 4 peserta pada hari kedua dalam pelatihan REB disebabkan oleh berbagai alasan, dari hasil wawancara yang dilakukan kepada subjek yang tidak mengikuti pelatihan selama satu hari sebut saja AG. AG mengungkapkan bahwa sampai sekarang ia masih mengalami kecemasan, hal ini dapat dibuktikan dari seringnya subjek mengeluh menderita sakit kepala ketika mengerjakan skripsi dan terhambatnya penyelesaian skripsinya. AG merasa ia dipersulit oleh dosen pembimbingnya dan sampai sekarang belum seminar. AG juga mengungkapkan alasan mengapa ia tidak mengikuti pelatihan karena ada acara, namun ketika peneliti mengkonfirmasi acara apa yang diikuti, AG mengatakan "saya lupa ada acara apa hari itu" dan ia berusaha mengalihkan pembicaraan, dan terus membahas kekesalan ia karena kesulitan menemui dosen pembimbing, dan gagalnya ia seminar karena proposal ditolak oleh dosen pembimbing dengan alasan masih kurang rapi dalam penyusunan kalimatnya. Padahal menurut AG proposal yang ia ajukan sudah baik, bahkan salah satu dosen sudah menyarankan ia untuk seminar, hingga sekarang subjek menunda pengerjaan skripsinya dan bermalas-malasan.

Sikap AG menolak untuk membicarakan ketidak hadirannya dalam pelatihan hari kedua dapat berarti sebuah perilaku penolakan, hal ini sesuai dengan yang dikatakan Feldman (2012) bahwa individu yang mengalami kecemasan cenderung untuk terjebak dengan pikiran yang tidak diinginkan atau perasaan yang mendorong individu untuk melakukan perilaku tertetu. Perilaku yang dimunculkan oleh subjek AG berupa penolakan dan menghindar untuk membicarakan hal yang tidak diinginkan, sehingga hal ini dapat memberikan indikasi bahwa AG 
mengalami peningkatan kecemasan setelah mengikuti pelatihan.

\section{SIMPULAN DAN SARAN}

\section{Simpulan}

Berdasarkan hasil penelitian mengenai efektivitas pelatihan rational emotive behavioral terhadap penurunan kecemasan menyusun skripsi pada mahasiswa Fakultas Saintek Universitas X di Yogyakarta dapat disimpulkan bahwa tidak ada perbedaan yang signifikan antara skor post test kelompok kontrol dan kelompok eksperimen. Begitu juga dengan skor pre test dan post test kelompok eksperimen, yang berarti tidak ada berbedaan yang signifikan antara sebelum dan setelah pelatihan. Hal ini berarti, pelatihan rasional emotive behavior kurang efektif dalam menurunkan kecemasan menyusun skripsi pada mahasiswa yang sedang menyusun skripsi, sehingga kedua hipotesis dalam penelitian ini ditolak.

\section{Saran}

Berdasarkan hasil penelitian ini, maka peneliti memberikan saran antara bagi peneliti selanjutnya antara lain :
Pertama: Peneliti selanjutnya bisa menambakan subjek penelitan, sehingga akan lebih jelas perbedaan antara sebelum dan sebelum diberikan pelatihan atau antara kelompok kontrol dan eksperimen.

Kedua: Waktu terapi sebaiknya dipilih pada saat hari libur saja, agar peserta yang terpilih dapat mengahdiri terapi secara keseluruhan dan lebih memastika komitmen peserta terapi agar tidak terjadi mortality pada saat terapi.

Ketiga: Interaksi kelompok dalam pelatihan lebih di tinggkatkan/diperbanyak agar proses pemahaman mengenai diri dan orang lain dapat berjalan dengan baik, menghindari pemilihan subjek yang memiliki ganguan lain selain gangguan yang akan diteliti, agar terapi dapat berjalan lebih maksimal.

Keempat: Treatment yang digunakan dalam pelatihan dapat menggunakan metode terapi kelompok yang memiliki interaksi lebih intens terhadap setiap peserta, dan dapat merubah pikiran irasionalnya

Kelima: Lebih memperhatikan informasi yang diberikan kepada peserta pada saat sebelum pelatihan agar tidak membuat peserta cemas dan khawatir dengan keadaanyang sedang dialaminya. 


\section{DAFTAR PUSTAKA}

Boeree, G. C. (2010). Personality Theories: Melacak Kepribadian Anda Bersama Psikolog Dunia. Yogyakarta : Ar-Ruzz Media.

Corey, G. (2010). Teori dan Praktek Konseling dan Psikoterapi. Bandung : Refika Aditama.

Deffenbacher, J. L., dan Susan L. H. (1985). Cognitive, Emotional and Physiological Component of test Anxiety. Journal Conseling Therapy and Practice. Vol 9.

Deffenbacher, J. L. (1998). Generalized Anxiety and Anxiety Management Training In V.E. Caballo (ED). International Hanbook of Cognitive and Behavioural Treatments. (pp. 227-249). Oxford, United Kingdom : Elsevier Science.

Desmita. (2009). Psikologi Perkembangan. Bandung : Remaja Rosdakarya.

Feldman, R.S. (2012). Pengantar Psikologi Understanding Psychology. Jakarta : Salemba Humanika.

Ghufron, M. N. dan Rini R. S. (2012). Teori-teori Psikologi. Yogyakarta : Ar-Ruzz Media.

Hardjana, A. M. (1994). Kiat Sukses Studi di Perguruan Tinggi. Yogyakarta : Kanisius.
Hurlock, E. B. (1999). Psikologi Perkembangan : Suatu Pendekatan Sepanjang Rentang Kehidupan. Edisi ke-5. Tjandrasa, $M$ \& Zarkasih, M. Pengalih Bahasa. Jakarta : Erlangga.

Latipun. (2010). Psikologi Eksperimen. Malang : UNM Pers.

Linayaningsih, F. (2007). Kecemasan pada Mahasiswa Fakultas Psikologi Universitas Katolik Soegijapranata dalam Mengerjakan Skripsi. Skripsi. Semarang : Fakultas Psikologi Universitas Katolik Soegijapranat.

Nevid, J. S., dkk. (2005). Psikologi Abnormal. Jilid 1. Jakarta : Erlangga.

Nindyanti, A. D., dkk. (2010). Buku Panduan Penulisan Skripsi atau Tugas Akhir Universitas Paramadina. Jakarta : Universitas Paramadina.

Prabawati, S. Y., Imelda F. (2012). Pedoman Penulisan Skripsi Program Studi Kimia. Yogyakarta : Fakultas Saintek dan Teknologi Universitas Islam Negeri Sunan Kalijaga.

Poerwardarminta, W. J. S. (1983) Kamus Umum Bahasa Indonesia. Jakarta : PT Balai Pustaka

Siburian, E., Karyono, \& Dian V. S. K. (2010). Pengaruh Rational Emotive 
Behavioral Therapy (REBT) dalam Menurunkan Kecemasan Menghadapi Masa Depan pada Penyalahguna NAPZA di Panti Rehabilitasi. Jurnal. Jurnal Psikologi UNDIP Vol. 7. No. 1.

Sobur, A. (2009). Psikologi Umum. Bandung : Pustaka Setia.

Suhendri, Sugiharto, \& Suwarjo. (2012). Efektifitas Konseling Rationalemotif untuk membantu siswa mengatasi kecemasan menghadapi ujian. Jurnal. Jurnal Bimbingan Konseling. Semarang : Prodi
Bimbingan Konseling Program Pascasarjana Universitas Nefgeri Semarang.

Sunberg, N. D., dkk. (2007). Psikologi Klinis. Yogyakarta : Pustaka Pelajar

Tim Penyusun Kamus Pusat Bahasa. (2002). Kamus Besar Bahasa Indonesia . Jakarta : Balai Pustaka.

Wilde, J. (2011) Rational Emotive and cognitive Behavioral Interventions for Children with Anxiety Disorder : A Group Conseling Curriculum. Journal Different Views of Anxiety Disorder. USA: In Tech 